\title{
Higher Doses of Subcutaneous IgG Reduce Resource Utilization in Patients with Primary Immunodeficiency
}

\author{
Elie Haddad • Melvin Berger • Edward C. Y. Wang • \\ Christopher A. Jones • Martin Bexon • \\ Jeffrey S. Baggish
}

Received: 21 July 2011 / Accepted: 4 December 2011 /Published online: 24 December 2011

(C) The Author(s) 2011. This article is published with open access at Springerlink.com

\begin{abstract}
The recommended dose of IgG in primary immunodeficiency (PID) has been increasing since its first use. This study aimed to determine if higher subcutaneous IgG doses resulted in improved patient outcomes by comparing results from two parallel clinical studies with similar design. One patient cohort received subcutaneous IgG doses that were 1.5 times higher than their previous intravenous doses (mean $213 \mathrm{mg} / \mathrm{kg} /$ week), whereas the other cohort received doses identical to previous subcutaneous or intravenous doses (mean $120 \mathrm{mg} / \mathrm{kg} /$ week). While neither cohort had any serious infections, the cohort maintained on higher mean IgG dose had significantly lower rates of non-serious infections ( 2.76 vs. 5.18 episodes/year, $P<0.0001$ ), hospitalization ( 0.20 vs. 3.48 days/year, $P<0.0001)$, antibiotic use ( 48.50 vs.
\end{abstract}

\author{
E. Haddad \\ Department of Pediatrics, and Microbiology and Immunology, \\ CHU Sainte-Justine, Université de Montréal, \\ Montreal, QC, Canada \\ M. Berger $\cdot$ C. A. Jones $\cdot$ J. S. Baggish $(\bowtie)$ \\ CSL Behring LLC, \\ 1020 First Avenue, P.O. Box 61501, King of Prussia, \\ PA 19406-0901, USA \\ e-mail: Jeff.Baggish@cslbehring.com \\ E. C. Y. Wang \\ Bayer Yakuhin, Ltd, \\ Tokyo, Japan \\ M. Bexon \\ CSL Behring AG, \\ Berne, Switzerland \\ Present Address: \\ C. A. Jones \\ Center for Clinical and Translational Science, \\ University of Vermont College of Medicine, \\ Burlington, VT, USA
}

72.75 days/year, $P<0.001$ ), and missed work/school activity ( 2.10 vs. 8.00 days/year, $P<0.001$ ). The higher-dose cohort had lower health care utilization and improved indices of well being compared to the cohort treated with traditional IgG doses.

Keywords Primary immunodeficiency · subcutaneous IgG replacement therapy infection rate $\cdot$ hospitalization rate . Hizentra

\section{Introduction}

Injection of immunoglobulins in its initial form was developed during the 1940s for use in the war effort [1] and was first used for primary immunodeficiency (PID) as a subcutaneous (SC) injection in 1952 by Dr. Ogden C. Bruton [2]. Since then, neither an optimal dose nor serum trough level has been established [3]. From the 1950s through the 1970s, Janeway and others administered IgG by intramuscular (IM) injections with doses of $25 \mathrm{mg} / \mathrm{kg} / \mathrm{week}$ or $100 \mathrm{mg} / \mathrm{kg} / \mathrm{month}$, resulting in serum levels of 110 to $260 \mathrm{mg} / \mathrm{dL}$, even though the landmark British Medical Research Council (MRC) study found that higher doses resulted in better outcomes [4]. In the early 1980s, introduction of IgG preparations that could be safely given intravenously (intravenous IgG, IVIG) made it possible to administer higher doses without severe reactions [5]. As IVIG and newer SC preparations of IgG (SCIG) were being adopted, the consensus regarding the optimal dose gradually grew to $400-800 \mathrm{mg} / \mathrm{kg} / \mathrm{month}$ to achieve serum levels of $500 \mathrm{mg} / \mathrm{dL}$ or greater.

One potential reason for the continued evolution of the optimal IgG dose may be that the objectives of treatment have been changing through the decades, as studies showed that higher IV doses which yielded higher serum trough 
levels were more effective in reducing the incidence of infection. The World Health Organization (WHO) defines "health" to be a state of "complete physical, mental and social well being and not merely the absence of disease or infirmity" [6]. Given that serious infections are efficiently prevented by IgG replacement, other outcomes that measure productivity, well being, and health utilization have been introduced in trials as measures for the comprehensive WHO definition of health [6]. In addition, immunologists often raise the dose to try to prevent progression of chronic lung disease and other end-organ complications of PID.

The PID Committee of the American Academy of Allergy, Asthma, and Immunology (AAAAI) concluded in a 2006 report that the dose of IgG should be titrated to achieve a trough level greater than $500 \mathrm{mg} / \mathrm{dL}$ in agammaglobulinemic patients and that trough levels greater than $800 \mathrm{mg} / \mathrm{dL}$ have the potential to improve pulmonary outcomes [7]. There have been few dose-ranging studies with IgG. In most recent licensing trials, the dose of IgG is based on the patients' previous treatment regimens without specifying how those doses were chosen by the patients' individual physicians. A survey of immunologists conducted recently by the AAAAI found that those immunologists who devote less than $10 \%$ of their practice to PID usually target a serum level of 500 to $750 \mathrm{mg} / \mathrm{dL}$, whereas more experienced immunologists whose PID patient population exceeds $10 \%$ of their practice were significantly more likely to target serum levels above $750 \mathrm{mg} / \mathrm{dL}(P=0.02)$ [8].

In 2010, the Canadian Blood Services published their review of dose-ranging studies and agreed that seven of the eight articles they reviewed concluded that outcomes were improved with higher doses of IVIG. Nevertheless, the authors concluded that although higher doses and serum trough levels appear to be associated with improved clinical response, clinical outcomes such as frequency of infections and days missed from school and work should be used to monitor the effectiveness of IgG therapy [9]. Recently, Lucas et al. showed, in a cohort of 90 patients mostly with common variable immunodeficiency (CVID), that the ranges of both IgG dose and IgG trough level were very large and that the goal of replacement therapy should be to improve clinical outcome and not to reach a particular IgG trough level [10]. Recent pooled analyses of multiple studies showed continuous relationships between IgG levels and incidence of pneumonia or other infections, with no sharp break points or plateaus [11, 12]. Also Bonagura et al. suggested that each patient has his/her own "biologic level" above which he/ she is infection-free [13]. No guidelines have identified a dose or serum level of IgG at which no additional clinical benefit is achieved, yet several payors have developed their own guidelines to limit reimbursement for IgG to only the dose needed to achieve a given serum IgG level regardless of the patient's clinical response. Other factors, such as periodic short supplies of $\operatorname{IgG}$, have also limited the prescribing of higher doses of IgG and raising of IgG trough levels in PID patients to achieve optimal clinical responses.

The purpose of this analysis was to determine if there is a relationship between the use of a higher SC dose of $\operatorname{IgG}$ and improvements in patient outcomes such as missed work/ school days, hospital days, days of antibiotic use, and infection rate. European and US health authorities required two different dosing levels for Hizentra ${ }^{\circledR}$ in their registration trials. This presented an opportunity to compare the outcomes from these independent cohorts of patients treated with different doses. This is the first analysis comparing patient outcomes achieved with two different SC dosing levels of Hizentra ${ }^{\circledR}$, a recently approved $20 \% \operatorname{IgG}$ preparation for SC use.

\section{Methods}

The two independent patient cohorts were from two clinical trials conducted roughly in parallel, one in the USA and the other primarily in the European Union (EU), both of which shared many features of patient selection and study design as part of a single clinical development program (Table I).

Both studies used an open-label, multi-center, single-arm design. The EU study enrolled patients from September 2007 to August 2009 [14]. Patients qualified for the study if they were male or female, aged from 2 to 65 years, and diagnosed with primary humoral deficiency as defined by the Pan-American Group for Immunodeficiency (PAGID) and the European Society for Immunodeficiencies (ESID) [15]. Prior to being enrolled in the European study, patients had to be successfully maintained on a stable (variation in dose not to exceed $10 \%$ ) IV or SC dose of IgG of 200 $800 \mathrm{mg} / \mathrm{kg} / \mathrm{month}$, to have at least three documented prestudy serum IgG trough levels of $\geq 500 \mathrm{mg} / \mathrm{dL}$, and to have experienced an acceptable clinical response as judged by their physician. Study patients were converted to an equivalent dose of Hizentra ${ }^{\circledR}$ administered weekly by the SC route. This patient population is referred to as the "1:1 dose" cohort. After a 12-week wash-in/wash-out phase, patients entered the 28-week efficacy period where the dose was held constant (1:1 dose) and outcomes were monitored.

The second cohort of patients came from a study that was conducted in the USA from November 2006 through October 2008 [16]. The study had similar pre-enrollment requirements for a stable pre-study dose with an acceptable clinical outcome. As requested by the US Food and Drug Administration (FDA), the dose for the 52-week efficacy phase was individually adjusted to give values for area under the curve of serum IgG vs. time (AUC) during SCIG therapy, which were equal to those recorded while the patients were still on the IV regimens prescribed by their physicians before enrollment. This resulted in a mean 1.5-fold increase in the SCIG dose 
compared to the previous IVIG dose. Additional details on the study designs are presented in the individual publications fully describing each study's effect on traditional endpoints such as infection rates and safety $[14,16]$.

The following secondary efficacy outcomes were assessed in both trials: missed work/school days due to infection, hospitalization days due to infection, and days of antibiotic therapy. These outcomes were reported as rate (days/patient/year) for the wash-in/wash-out and efficacy periods and served as the basis for this report. Local tolerability was assessed differently in the two studies. In the EU study, only patient's perception $24-72 \mathrm{~h}$ after the administration was recorded, while in the US study, the investigator assessed local tolerability within 15-45 min of the end of the infusion in addition to the patient's perception.

Differences in the distribution of categorical variables between the two cohorts were compared using Chi-square test. Mean age, weight, IgG dose, and serum IgG trough levels were compared using Student's $t$-test. The rates of infection, hospitalization, antibiotic use, and missed work/ school days were compared between cohorts using Poisson regression, with and without controlling for key demographic differences between the cohorts, i.e., sex, age group (2-16/ $\geq 17$ years), and PID type (XLA/CVID and other) using the days within the study as offset. The factor PID type was dropped from the multi-factorial analysis for hospitalization due to convergence problems. All analyses were performed using SAS Version 9.2 of the SAS System, SAS Institute Inc., Cary, NC, USA. A level of significance of $5 \%$ was set. No adjustment for multiplicity and no checks of model assumptions were performed.

\section{Results}

The characteristics of the two patient cohorts are summarized in Table II. Because similar study protocols were used to recruit patients from different continents, the two patient populations were generally similar. However, the EU population included more male, pediatric, and X-linked agammaglobulinemia (XLA) patients.

In the EU study, the mean weekly $\operatorname{IgG}$ dose administered during the efficacy period was $120 \mathrm{mg} / \mathrm{kg}$ (range $59-243 \mathrm{mg} / \mathrm{kg}$ ), resulting in a mean trough level of $810 \mathrm{mg} / \mathrm{dL}$ (standard deviation [SD] $144 \mathrm{mg} / \mathrm{dL}$ ). In the US study, the mean weekly IgG dose administered during the efficacy period was $213 \mathrm{mg} / \mathrm{kg}$ (range $72-379 \mathrm{mg} / \mathrm{kg}$ ), resulting in a mean trough level of $1,253 \mathrm{mg} / \mathrm{dL}$ (SD $321 \mathrm{mg} / \mathrm{dL}$ ). Of note, patients in the EU cohort had received lower mean IgG doses during their previous therapy (mean \pm SD $107 \pm$ $29 \mathrm{mg} / \mathrm{kg} /$ week for IVIG treatment and $132 \pm 50 \mathrm{mg} / \mathrm{kg} /$ week

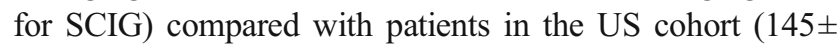
$48 \mathrm{mg} / \mathrm{kg} /$ week).

No serious bacterial infections were reported in either study (Table III). However, the rate of other infections was 2.76 events/patient/year in the 1.5:1 dose cohort vs. 5.18 events/ patient/year in the 1:1 dose cohort $(P<0.0001)$. The rate of days hospitalized in the 1.5:1 dose group was 0.2 days/patient/ year vs. 3.48 days/patient/year in the $1: 1$ dose group $(P<0.0001)$. The proportion of patients who became hospitalized was lower in the 1.5:1 dose group (2.6 compared to 8.7 for the 1:1 cohort); however, the difference observed was not statistically significant $(P=0.2423)$. The rate of days of antibiotic use was 48.50 days/patient/year in the 1.5:1 dose group

Table I Comparison of the Hizentra ${ }^{\circledR}$ US and EU clinical registration trials

\begin{tabular}{|c|c|c|}
\hline & $\begin{array}{l}\text { Hizentra }{ }^{\circledR} \text { trial enrolling patients primarily } \\
\text { from the } \mathrm{EU}\end{array}$ & Hizentra ${ }^{\circledR}$ trial enrolling patients from the USA \\
\hline \multirow[t]{3}{*}{ Pre-trial requirements } & - 6 months of stable outcomes & - 6 months of stable outcomes \\
\hline & - Stable IV or SC IgG dosing & - Stable IV IgG dosing \\
\hline & - 3 trough levels $\geq 500 \mathrm{mg} / \mathrm{dL}$ & - 3 trough levels $\geq 500 \mathrm{mg} / \mathrm{dL}$ \\
\hline Inclusion/exclusion criteria & Same $[14]$ & Same [16] \\
\hline Wash-in/wash-out period & 12 weeks & 12 weeks \\
\hline $\begin{array}{l}\text { Hizentra } ₫ \text { dose during } \\
\text { wash-in/wash-out period }\end{array}$ & Equivalent to pre-trial IgG dose & 1.3 times the pre-trial IgG dose \\
\hline Efficacy period & 28 weeks & 52 weeks \\
\hline Hizentra ${ }^{\circledR}$ dose during efficacy period & Equivalent to pre-trial IgG dose (1:1 dose) & 1.5 times the pre-trial $\operatorname{IgG} \operatorname{dose}^{\mathrm{a}}(\mathbf{1 . 5 : 1}$ dose $)$ \\
\hline Outcomes measured & $\begin{array}{l}\text { Same (IgG trough levels, rate of infections, } \\
\text { hospitalization days, days of antibiotic use, } \\
\text { and missed work/school days) }\end{array}$ & $\begin{array}{l}\text { Same (IgG trough levels, rate of infections, } \\
\text { hospitalization days, days of antibiotic use, } \\
\text { and missed work/school days) }\end{array}$ \\
\hline
\end{tabular}

\footnotetext{
${ }^{a}$ Based on a US FDA-mandated dose adjustment coefficient determined in pharmacokinetic sub-study [27] to maintain area under the concentration-time curve following switch from IVIG

$E U$ European Union, $I V$ intravenous, $S C$ subcutaneous, US United States
} 
Table II Summary of baseline and dosing characteristics of the patients in each trial
$A R A G$ autosomal recessive agammaglobulinemia, CVID common variable immunodeficiency, EU European Union, $N / A$ not applicable, $S D$ standard deviation, US United States, $X L A$ X-linked agammaglobulinemia

${ }^{\mathrm{a}}$ Chi-square test

${ }^{\mathrm{b}}$ Student's $t$-test

${ }^{\mathrm{c}}$ Mean of individual patient median values

\begin{tabular}{|c|c|c|c|}
\hline Parameter & $\begin{array}{l}1: 1 \text { dose cohort } \\
\text { (EU) }(N=46)\end{array}$ & $\begin{array}{l}1.5: 1 \text { dose cohort } \\
\text { (US) }(N=38)\end{array}$ & $\begin{array}{l}P \text {-value of difference: } \\
\text { between cohorts }\end{array}$ \\
\hline \multicolumn{4}{|l|}{ Gender $(\%)$} \\
\hline Female & 33 & 55 & \multirow[t]{2}{*}{$0.0368^{\mathrm{a}}$} \\
\hline Male & 67 & 45 & \\
\hline \multicolumn{4}{|l|}{ Age (years) } \\
\hline Mean (SD) & $21.5(15.6)$ & $36.3(19.5)$ & $0.0003^{\mathrm{b}}$ \\
\hline \multicolumn{4}{|l|}{ Age group (\%) } \\
\hline $2-11$ years & 37 & 8 & \multirow[t]{3}{*}{$0.0134^{\mathrm{a}}$} \\
\hline $2-16$ years & 50 & 24 & \\
\hline$>16$ years & 50 & 76 & \\
\hline \multicolumn{4}{|l|}{ Weight (kg) } \\
\hline Mean (SD) & $52.1(24.7)$ & $70.0(21.3)$ & $0.0006^{\mathrm{b}}$ \\
\hline \multicolumn{4}{|l|}{ PID diagnosis $(\%)$} \\
\hline CVID & 61 & 95 & \multirow[t]{3}{*}{$0.0014^{\mathrm{a}}$} \\
\hline XLA & 37 & 5 & \\
\hline ARAG & 2 & 0 & \\
\hline $\begin{array}{l}\text { Mean weekly doses before } \\
\text { study start }(\mathrm{mg} / \mathrm{kg})\end{array}$ & 122 & 144 & $\mathrm{~N} / \mathrm{A}$ \\
\hline $\begin{array}{l}\text { Median IgG levels before } \\
\text { study start }(\mathrm{mg} / \mathrm{dL})\end{array}$ & & & $\mathrm{N} / \mathrm{A}$ \\
\hline $\operatorname{Mean}^{\mathrm{c}}(\mathrm{SD})$ & 749 (157) & $1,010(257)$ & \\
\hline \multicolumn{4}{|l|}{$\begin{array}{l}\text { Weekly dose of Hizentra }{ }^{\circledR} \\
\text { during the efficacy period } \\
(\mathrm{mg} / \mathrm{kg})\end{array}$} \\
\hline Mean $^{\mathrm{c}}$ (range) $[\mathrm{SD}]$ & $120(59-243)[34]$ & $213(72-379)[78]$ & $<0.0001^{\mathrm{b}}$ \\
\hline \multicolumn{4}{|l|}{$\begin{array}{l}\text { Mean trough level during the } \\
\text { efficacy period }(\mathrm{mg} / \mathrm{dL})\end{array}$} \\
\hline $\operatorname{Mean}^{\mathrm{c}}(\mathrm{SD})$ & $810(144)$ & $1,254(322)$ & $<0.0001^{\mathrm{b}}$ \\
\hline
\end{tabular}

vs. 72.75 days/patient/year in the 1:1 dose group $(P<0.001)$. Work/school days were missed at a rate of 2.06 days/patient/ year in the 1.5:1 dose group vs. 8.00 in the 1:1 dose group $(P<0.001)$. The proportion of patients missing one or more work/school days per year was lower in the 1.5:1 dose cohort, but the difference observed did not reach statistical significance $(P=0.2637)$. The results of the EU study were substantially affected by the data of a child with recurrent pneumonia who missed 71 work/school days and spent 63 days in hospital $[14,17]$. Therefore, a sensitivity analysis excluding this child was performed. The results of this analysis were similar to those for the entire populations (Table III).

An analysis of rate of infection by month of the year was performed to account for the different duration of the two studies. The results showed an even distribution of onset of infections over the year in the US study (infection rate range, 1.14-3.82 infections/patient/year), while a seasonal variability was noted in the EU study. In the EU study, the rate of infection by month of onset ranged between 2.27 and $11.21 \mathrm{infections/patient/year,} \mathrm{with} \mathrm{the} \mathrm{lowest} \mathrm{rates} \mathrm{of} \mathrm{infection}$ observed in June (2.27 infections/subject/year) and July (2.71 infections/subject/year) and the highest rates in January (11.21 infections/subject/year) and December (9.34 infections/subject/year). However, the overall rates of infection did not show any particular trend; thus, the rates for September, October, and November were similar to those for February, April, and August (5.17-6.65).

The rate of non-serious infections was significantly different between the two cohorts. To analyze further the reasons for this difference, an analysis of infection rates in patients experiencing more than four infections during the efficacy periods of the two studies was performed (Table IV). A substantial contribution to the annualized rate of infections in the EU study was due to 12 patients who experienced a total of 79 infection episodes in the efficacy period, resulting in a statistically significant difference between the two cohorts (12.05 in the $1: 1$ cohort and 8.38 in the $1.5: 1$ cohort; $P=0.0430)$. In the 1.5:1 cohort (USA), seven patients experienced a total of 51 infection episodes (Table IV).

Because the two cohorts differed in gender, age, and PID type, a Poisson regression was conducted by controlling these differences as covariates in the analysis across the efficacy period of each study. The results of this analysis confirmed the significant differences in all four study 
Table III Comparison of health outcomes in the two cohorts of PID patients treated with different doses of subcutaneous Hizentra ${ }^{\circledR}$

\begin{tabular}{|c|c|c|c|c|}
\hline & \multirow{2}{*}{$\begin{array}{l}1: 1 \text { dose cohort } \\
(\mathrm{EU})(N=46)\end{array}$} & \multirow{2}{*}{$\begin{array}{l}1.5: 1 \text { dose cohort } \\
\text { (US) }(N=38)\end{array}$} & \multicolumn{2}{|c|}{ Analysis of differences between cohorts } \\
\hline & & & $\begin{array}{l}\text { Univariate } \\
\text { comparisons }\end{array}$ & $\begin{array}{l}\text { Multi-factorial comparisons } \\
\text { adjusting for covariables }\end{array}$ \\
\hline Rate of serious infections (events/patient/year) & 0 & 0 & & \\
\hline Rate of infections (events/patient/year) & 5.18 & 2.76 & $<0.0001^{\mathrm{b}}$ & $<0.0001^{\mathrm{b}}$ \\
\hline Sensitivity analysis ${ }^{\mathrm{a}}$ & 5.16 & & $<0.0001^{\mathrm{b}}$ & $<0.0001^{\mathrm{b}}$ \\
\hline $\begin{array}{l}\text { Rate of days of hospitalization due to infection } \\
\text { (days/patient/year) }\end{array}$ & 3.48 & 0.20 & $<0.0001^{\mathrm{b}}$ & $<0.0001^{b, d}$ \\
\hline Sensitivity analysis ${ }^{\mathrm{a}}$ & 0.95 & & $0.0003^{\mathrm{b}}$ & $\mathrm{N} / \mathrm{A}^{\mathrm{e}}$ \\
\hline Percent of patients hospitalized due to infection & 8.7 & 2.6 & $0.2423^{c}$ & N/A \\
\hline Sensitivity analysis ${ }^{\mathrm{a}}$ & 6.67 & & $0.3925^{\mathrm{c}}$ & \\
\hline $\begin{array}{l}\text { Rate of days with antibiotics for treatment or } \\
\text { prophylaxis of infection (days/patient/year) }\end{array}$ & 72.75 & 48.5 & $<0.0001^{\mathrm{b}}$ & $<0.0001^{\mathrm{b}}$ \\
\hline Sensitivity analysis ${ }^{\text {a }}$ & 66.62 & & $<0.0001^{\mathrm{b}}$ & $<0.0001^{\mathrm{b}}$ \\
\hline $\begin{array}{l}\text { Rate of days missed off work/school due to infection } \\
\text { (days/patient/year) }\end{array}$ & 8.0 & 2.06 & $<0.0001^{\mathrm{b}}$ & $<0.0001^{\mathrm{b}}$ \\
\hline Sensitivity analysis a & 5.25 & & $<0.0001^{\mathrm{b}}$ & $<0.0001^{\mathrm{b}}$ \\
\hline $\begin{array}{l}\text { Percent of patients missing } \geq 1 \text { day off work/school } \\
\text { per year due to infection }\end{array}$ & 43.5 & 31.6 & $0.2637^{\mathrm{c}}$ & N/A \\
\hline Sensitivity analysis ${ }^{\text {a }}$ & 42.2 & & $0.3179^{\mathrm{c}}$ & \\
\hline
\end{tabular}

EU European Union, N/A not applicable, US United States

${ }^{a}$ Sensitivity analysis of health outcomes after exclusion of one patient from the 1:1 cohort (EU) who suffered from recurrent pneumonia

${ }^{\mathrm{b}} P$-value from Poisson regression

${ }^{\mathrm{c}} P$ value from Chi-square test

${ }^{\mathrm{d}}$ The factor PID type was dropped from the multi-factorial analysis for hospitalization due to convergence problems

${ }^{\mathrm{e}}$ Analysis not performed due to non-convergence of the model

outcomes $(P<0.0001$, Table III). In addition, an analysis controlling for the length of the observation period was performed to compare the 1.5:1 and 1:1 cohorts up to the 28 -week time point. During the first 28 weeks of the efficacy period in the 1.5:1 cohort, the rates of infection (2.7 events/patient/year), hospitalization ( 0 days/patient/year), antibiotic use (49.5 days/ patient/year), and missed work/school days (1.61 days/patient/ year) were similar to those observed during the entire 54-week efficacy period. Consequently, all efficacy outcomes observed in the 1.5:1 dose group were improved compared to those in the 1:1 dose group, regardless of the length of the observation period.

The most common adverse event reported in each study was local reactions at the injection site. The rate of local reactions was 0.59 events/infusion in the 1.5:1 cohort and 0.06 events/infusion in the $1: 1$ cohort. Most of the local reactions were of mild or moderate intensity $(99.7 \%$ in the 1.5:1 cohort and $99.1 \%$ in the $1: 1$ cohort). The difference in the rate of local reactions between the studies was likely due to the different assessment of local tolerability.

Table IV Analysis of infection rates in the two cohorts of PID patients

\begin{tabular}{llll}
\hline & $\begin{array}{l}1: 1 \text { dose cohort } \\
(\text { EU) }(N=46)\end{array}$ & $\begin{array}{l}1.5: 1 \text { dose cohort } \\
(\text { US) }(N=38)\end{array}$ & $\begin{array}{l}\text { Analysis of differences } \\
\text { between cohorts }\end{array}$ \\
\hline $\begin{array}{l}\text { Number (\%) of patients without infections in efficacy period } \\
\text { Number (\%) of patients with 1-4 infection episodes in efficacy period }\end{array}$ & $10(21.7)$ & $7(18.4)$ & $0.7064^{\mathrm{a}}$ \\
Number (\%) of patients with $>4$ infection episodes in efficacy period & $24(52.2)$ & $24(63.2)$ & $0.3113^{\mathrm{a}}$ \\
Annualized rate of infection in patients with $>4$ infection episodes in efficacy period & $12(26.1)$ & $7(18.4)$ & $0.4032^{\mathrm{a}}$ \\
\hline
\end{tabular}

EU European Union, N/A not applicable, US United States

${ }^{\text {a }} P$ value from Chi-square test

${ }^{\mathrm{b}} P$ value from Poisson regression 


\section{Discussion}

Two independent trials of Hizentra ${ }^{\circledR}$ were conducted in the USA and the EU with similar designs except that regulatory authorities in the USA required that patients be converted to a SC dose that was 1.5 times higher than the IV dose they were previously using. The US FDA requested that SCIG dose be adjusted to achieve an equivalent AUC of IgG serum levels when patients were converted from monthly IV dosing to weekly SC dosing. Calculations based on IgG serum levels obtained from patients under IVIG indicated that it would require a SC dose that was 1.5 times the IV dose to achieve an equivalent AUC. On the other hand, the European Medicines Agency (EMA) accepted the direct conversion of the monthly IV dose to a weekly SC dose by simple division of the monthly dose into weekly increments, as long as this resulted in non-inferior IgG levels compared to the trough on previous therapy. Indeed, experts disagreed when asked if IgG efficacy is driven by peak, trough, or AUC serum levels [12]. As a result, two parallel registration trials with similar designs were initiated with different SCIG dose levels, creating a unique opportunity to explore the effect of $\operatorname{IgG}$ dose on treatment outcomes in stable well-managed PID patients.

By comparing the two cohorts, we found that the 1:1 and 1.5:1 doses of SCIG were equally effective in achieving freedom from serious life-threatening bacterial infections. However, we showed that in the 1.5:1 dose (USA) cohort, there were significantly better function (fewer work/school days missed), significantly less health care utilization (fewer hospitalization days and less antibiotic use), and a significantly lower rate of non-serious infections. This two-cohort approach offers some valuable insights and strongly suggests a positive effect of 1.5:1 IgG dose on outcomes.

These findings should be interpreted with caution as the comparison of results from two independent studies differs from that of results collected in a single randomized trial. Factors not controlled statistically or by randomization may be contributing to the differences observed (baseline PID severity, practice differences between the EU and the USA, etc.). As the differences in behaviors (work/school attendance, antibiotic use) correlated with differences in infection rate, it seems unlikely that the improvement in clinical outcomes in the US study was purely a function of the differences in patient behavior between the USA and the EU. Also, there were several differences between the two studies that might limit a direct side-by-side comparison. First, the US study was longer than the EU study (54-week vs. 28-week efficacy period, respectively). Second, the prespecified primary endpoints were different. In the US study, the primary endpoint was the annual rate of serious bacterial infections, while in the EU study, the primary endpoint was the total serum IgG trough level. Third, the EU study had more pediatric and XLA patients, while the US study had a larger sample size and a higher dropout rate ( $43 \%$ vs. $16 \%$ for the EU study $[14,16])$. Nevertheless, by controlling the gender, age, and PID type as covariates, the significant differences in all four study outcomes were confirmed, thereby strongly suggesting that the differences in study design and population were very unlikely responsible for the better outcomes observed in the US cohort. Fourth, US patients were treated with higher doses for a longer period of time as they had received higher pre-study IgG doses (144 vs. $122 \mathrm{mg} / \mathrm{kg}$ in the EU study). However, this difference does not change the overall result that the more IgG patients received, the better indices of health they had.

An alternate explanation for these findings could be that the PID patients enrolled in the USA had milder disease or had better outcomes in their pre-study period compared to the EU cohort. Unfortunately, no efficacy assessment was done prior to study initiation to determine if the two groups were similar at baseline.

In spite of these research design limitations, it is interesting to note that these findings do not contradict previous dose-ranging studies. Indeed, of the ten previously published IgG dose-response studies [3, 18-26] summarized in Table V, only the first two studies published in 1984 did not show a dose-response relationship. None of the ten studies identified a plateau or flattening in the dose-response function at the top of the dose range above which no further outcome improvement was achieved. Moreover, it was recently shown by Orange et al., in a meta-analysis that included 17 studies with 676 patients treated with IVIG and 2,127 patient-years of follow-up, that pneumonia risk was directly related to trough level of $\operatorname{IgG}$ and that this risk could be progressively reduced by higher trough $\mathrm{IgG}$ levels of up to at least $1,000 \mathrm{mg} / \mathrm{dL}$ [12]. Similarly, Berger showed that the incidence of non-serious infections was inversely proportional to the steady state serum IgG levels achieved in different SCIG studies [11].

None of these studies assessed if the outcomes achieved by patients from higher-dose groups were comparable to healthy (non-PID) individuals with a "normal" rate of infection or comparable to individuals with a state of "complete physical, mental and social well being." In our study, the PID patients in the 1.5:1 dose group have missed 2.06 work/school days/patient/year due to infection alone. The US Bureau of Labor Statistics reports that, on average, in 2010, US workers missed 2.3 days/year due to any infections, other illnesses, or injuries [26]. This would indicate that PID patients treated with the 1.5:1 dose may still have sub-optimal experience of normal activity if other reasons for missed activity are considered. While all PID studies focus on the lack of disease, specifically a reduction in the rate of infections, not all include measures assessing the 
Table V A summary of the dose comparison studies of IgG in PID published to date

\begin{tabular}{|c|c|c|c|c|c|c|c|c|}
\hline Publication & Route & IgG preparation & $\begin{array}{l}\text { Number of } \\
\text { patients }\end{array}$ & Study design & Outcomes monitored & Results & $\begin{array}{l}\text { Dose-response } \\
\text { relationship } \\
\text { found }\end{array}$ & $\begin{array}{l}\text { Identified upper } \\
\text { dose with no } \\
\text { incremental benefit }^{\mathrm{a}}\end{array}$ \\
\hline Hill, 1971 [4] & $\begin{array}{l}\text { Not } \\
\quad \text { available }\end{array}$ & Not available & 176 & Open-label & & $\begin{array}{l}0.05 \mathrm{~g} / \mathrm{kg} \text { was } \\
\text { superior to } 0.025 \mathrm{~g} / \mathrm{kg} \\
\text { (reduced frequency } \\
\text { of febrile episodes, } \\
\text { otitis media, and } \\
\text { pneumonia) }\end{array}$ & No & No \\
\hline $\begin{array}{l}\text { Montanaro, } \\
1984[23]\end{array}$ & IV & Gamimune $10 \%$ & 11 & Randomized & $\begin{array}{l}\text { No patient outcomes, } \\
\text { time from } 500 \mathrm{mg} / \mathrm{kg} \\
\text { dose to serum level } \\
\text { under } 400 \mathrm{mg} / \mathrm{dL}\end{array}$ & $\begin{array}{l}150 \text { and } 500 \mathrm{mg} / \mathrm{kg} \text { were } \\
\text { not differentiated }\end{array}$ & $\mathrm{No}^{\mathrm{b}}$ & N/A \\
\hline $\begin{array}{l}\text { Ochs, } 1984 \\
{[20]}\end{array}$ & IV & Gamimune $10 \%$ & 35 & $\begin{array}{l}\text { Two-arm randomized, } \\
12 \text { month }\end{array}$ & $\begin{array}{l}\text { Number of infections, } \\
\text { antibiotic use, days } \\
\text { missed }\end{array}$ & $\begin{array}{l}100 \text { and } 400 \mathrm{mg} / \mathrm{kg} \text { are } \\
\text { equally effective }\end{array}$ & No & N/A \\
\hline $\begin{array}{c}\text { Bernatowska, } \\
1987 \text { [24] }\end{array}$ & IV & Endoglobulin & 12 & $\begin{array}{l}\text { Two-arm randomized } \\
\text { cross-over with } \\
\text { retrospective vhistory, } \\
12 \text { month }\end{array}$ & $\begin{array}{l}\text { Fever, infections, } \\
\text { antibiotic use, lung } \\
\text { function }\end{array}$ & $\begin{array}{l}500 \mathrm{mg} / \mathrm{kg} \text { is superior to } \\
150 \mathrm{mg} / \mathrm{kg} \text {, especially in } \\
\text { children with more } \\
\text { symptoms }\end{array}$ & Yes & No \\
\hline $\begin{array}{l}\text { Roifman, } \\
1987[21]\end{array}$ & IV & Sandoglobulin & 12 & $\begin{array}{l}\text { Two-arm randomized } \\
\text { cross-over }\end{array}$ & $\begin{array}{l}\text { Infections, lung } \\
\text { function }\end{array}$ & $\begin{array}{l}600 \mathrm{mg} / \mathrm{kg} \text { is superior to } \\
200 \mathrm{mg} / \mathrm{kg} ;>500 \mathrm{mg} / \mathrm{dL} \\
\text { is superior to }<500 \mathrm{mg} / \mathrm{dL}\end{array}$ & Yes & No \\
\hline $\begin{array}{l}\text { Liese, } \\
1992 \text { [22] }\end{array}$ & IV, IM & Various & 29 & $\begin{array}{l}\text { Retrospective chart } \\
\text { review }\end{array}$ & $\begin{array}{l}\text { Pneumonia, days } \\
\text { hospitalized }\end{array}$ & $\begin{array}{l}400 \mathrm{mg} / \mathrm{kg} \text { q3 weeks IV is } \\
\text { superior to } 200 \mathrm{mg} / \mathrm{kg} \mathrm{q} 3 \\
\text { weeks IV or } 100 \mathrm{mg} / \mathrm{kg} \\
\text { q3 weeks IM }\end{array}$ & Yes & No \\
\hline $\begin{array}{l}\text { Pruzanski, } \\
1996[25]\end{array}$ & IV & Iveegam & 21 & $\begin{array}{l}\text { Three-arm } \\
\text { randomized }\end{array}$ & Infections & $\begin{array}{l}600 \text { or } 400 \mathrm{mg} / \mathrm{kg} \text { is } \\
\text { superior to } 200 \mathrm{mg} / \mathrm{kg} \text {; }\end{array}$ & Yes & $\mathrm{No}^{\mathrm{c}}$ \\
\hline $\begin{array}{l}\text { Quartier, } \\
1999 \text { [19] }\end{array}$ & IV & Various & 31 & $\begin{array}{l}\text { Retrospective chart } \\
\text { review }\end{array}$ & $\begin{array}{l}\text { Hospitalization for } \\
\text { infection }\end{array}$ & $\begin{array}{l}>800 \mathrm{mg} / \mathrm{dL} \text { is superior to } \\
500-800 \mathrm{mg} / \mathrm{dL} \text { or }<500 \\
\mathrm{mg} / \mathrm{dL}\end{array}$ & Yes & No \\
\hline $\begin{array}{l}\text { Eijkhout, } \\
2001[18]\end{array}$ & IV & $\begin{array}{l}\text { Immunoglobulin } \\
\text { IV }\end{array}$ & 43 & $\begin{array}{l}\text { Two-arm randomized } \\
\text { cross-over, } 9 \text { month }\end{array}$ & $\begin{array}{l}\text { Infection rate and } \\
\text { duration }\end{array}$ & $\begin{array}{l}600 / 800 \mathrm{mg} / \mathrm{kg} \text { is superior } \\
\text { to } 300 / 400 \mathrm{mg} / \mathrm{kg} ; 940 \\
\mathrm{mg} / \mathrm{dL} \text { is superior to } 630 \\
\mathrm{mg} / \mathrm{dL}\end{array}$ & Yes & No \\
\hline $\begin{array}{l}\text { Roifman, } \\
2003[3]\end{array}$ & IV & $\begin{array}{l}\text { Gamunex, } 10 \% \\
\text { Gamimune-N } 10 \%\end{array}$ & $\begin{array}{l}73 \\
73\end{array}$ & $\begin{array}{l}\text { Findings based on } \\
\text { post-hoc analysis } \\
\text { of data }\end{array}$ & Infection rate & $\begin{array}{l}>900 \mathrm{mg} / \mathrm{dL} \text { is superior to } \\
>700-900 \mathrm{mg} / \mathrm{dL} ;>700- \\
\quad 900 \mathrm{mg} / \mathrm{dL} \text { is superior to }< \\
700 \mathrm{mg} / \mathrm{dL}\end{array}$ & Yes & No \\
\hline $\begin{array}{l}\text { Favre, } \\
2005[28]\end{array}$ & IV & Sandoglobulin & 7 & $\begin{array}{l}\text { Observational, } 116 \\
\text { patient-years }\end{array}$ & Infections & $\begin{array}{l}400 \mathrm{mg} / \mathrm{kg} \mathrm{q} 3 \text { weeks is } \\
\text { superior to } 200 \mathrm{mg} / \mathrm{kg} \\
\mathrm{q} 3 \text { weeks }\end{array}$ & Yes & No \\
\hline This study & $\mathrm{SC}$ & Hizentra & 84 & $\begin{array}{l}\text { Open-label, multi- } \\
\text { center, single-arm }\end{array}$ & $\begin{array}{l}\text { Infections, missed } \\
\text { work/school } \\
\text { days due to } \\
\text { infection, } \\
\text { hospitalization days } \\
\text { due to infection, and } \\
\text { days of antibiotic } \\
\text { therapy }\end{array}$ & $\begin{array}{l}\text { Mean weekly IgG dose of } \\
120 \mathrm{mg} / \mathrm{kg} \text { improved } \\
\text { secondary efficacy } \\
\text { outcomes compared to } \\
213 \mathrm{mg} / \mathrm{kg}\end{array}$ & $\begin{array}{l}\text { Yes, for some } \\
\text { outcomes }\end{array}$ & No \\
\hline
\end{tabular}

$I V$ intravenous, $I M$ intramuscular, $N / A$ not applicable

${ }^{a}$ This pertains to the flat portion of the dose-response curve where an increase in the dose is not associated with any additional clinical response

${ }^{\mathrm{b}}$ No response or outcomes were monitored, only effect of dose on serum levels

${ }^{\mathrm{c}}$ The dose-response pattern observed was not consistent with a normal dose-response relationship, in that the highest dose had inferior outcomes to the lowest dose

extent to which a patient achieves the WHO definition of health or some other measure of well being or function.

Efficacy measures such as antibiotic use, hospitalization rate, and missed work/school days serve as clinical and economic indicators in clinical trials; however, they do not represent the total spectrum of the patient benefit which can be achieved through optimal IgG dose. Other associated patient benefit effects may be occurring with $1.5: 1 \mathrm{IgG}$ doses, even if they were not measured. For example, a child may not miss school with low-grade infections but cannot partake in the more physical aspects of classroom and playground life. An adult may not be so sick as to warrant time off work, but persistently lacks the energy for a normal social life. The 1.5:1 dose is therefore expected to be associated with a greater normalcy of life experiences, moving patients closer to a life without breakthrough infections or chronic lack of well being. Moreover, the long-term sequelae of frequent infections accumulate over time, leading to structural changes in lung or sinus tissue. Preventing such sequelae may lead to further improvements in long-term patient 
outcomes and potential reductions in long-term health care costs. Higher IgG doses may also help reduce the frequency of chronic infections. Living a life with fewer infections may offer opportunities for PID patients which may otherwise not be afforded.

\section{Conclusions}

The objectives of PID treatment continue to evolve. Successful treatment can no longer be measured solely by the degree to which serious bacterial infections are prevented. Other clinical and functional outcomes must be measured as well. The findings that we report here suggest that increasing the doses of IgG might produce improvements in such outcomes, at least in some patients with frequent infections.

As the agenda of treatment of PID patients move forward beyond life or death interventions, the goals of IgG therapy may move toward optimization of health state outcomes and the full achievement of health and a normal life. The higherdose cohort in this comparison recorded improved indices of well being compared to those treated with traditional doses of IgG. This study, despite its limitations, suggests that increasing the SCIG doses is associated with significantly fewer infections, days of hospitalization, days of antibiotic use, and days of missed activities, resulting in reduced resource utilization.

Acknowledgements We would like to acknowledge the assistance of John-Philip Lawo for the statistical analyses and Dr. John Mackowiak in preparing the early stages of this manuscript.

Disclosure of potential conflicts of interest Dr. Haddad reports consultant fees from CSL Behring and Talecris, and research support from CSL Behring and Talecris; Dr. Wang was an employee of CSL Behring during the early stages of this study and manuscript preparation; Dr. Berger, Dr. Jones, Dr. Bexon, Dr. Baggish, and J.P. Lawo are employees of CSL Behring. No other potential conflicts of interest were reported.

Open Access This article is distributed under the terms of the Creative Commons Attribution Noncommercial License which permits any noncommercial use, distribution, and reproduction in any medium, provided the original author(s) and source are credited.

\section{References}

1. Berger M. A history of immune globulin therapy, from the Harvard crash program to monoclonal antibodies. Curr Allergy Asthma Rep. 2002;2:368-78.

2. Bruton OC. Agammaglobulinemia. Pediatrics. 1952;9:722-8.

3. Roifman CM, Schroeder H, Berger M, Sorensen R, Ballow M, Buckley RH, et al. Comparison of the efficacy of IGIV-C, $10 \%$ (caprylate/chromatography) and IGIV-SD, 10\% as replacement therapy in primary immune deficiency. A randomized doubleblind trial. Int Immunopharmacol. 2003;3:1325-33.

4. Hill LE. Hypogammaglobulinaemia in the United Kingdom. 3. Clinical features of hypogammaglobulinaemia. Spec Rep Ser Med Res Counc (GB). 1971;310:9-34.

5. Appropriate uses of human immunoglobulin in clinical practice: memorandum from an IUIS/WHO meeting. Bull World Health Organ. 1982;60:43-7.

6. WHO. Preamble to the Constitution of the World Health Organization as adopted by the International Health Conference, New York, 19-22 June, 1946; signed on 22 July 1946 by the representatives of 61 States (Official Records of the World Health Organization, no. 2 , p. 100) and entered into force on 7 April 1948. 1948.

7. Orange JS, Hossny EM, Weiler CR, Ballow M, Berger M, Bonilla FA, et al. Use of intravenous immunoglobulin in human disease: a review of evidence by members of the Primary Immunodeficiency Committee of the American Academy of Allergy. Asthma and Immunology. J Allergy Clin Immunol. 2006;117:S525-53.

8. Yong PL, Boyle J, Ballow M, Boyle M, Berger M, Bleesing J, et al. Use of intravenous immunoglobulin and adjunctive therapies in the treatment of primary immunodeficiencies: a working group report of and study by the Primary Immunodeficiency Committee of the American Academy of Allergy Asthma and Immunology. Clin Immunol. 2010;135:255-63.

9. Shehata N, Palda V, Bowen T, Haddad E, Issekutz TB, Mazer B, et al. The use of immunoglobulin therapy for patients with primary immune deficiency: an evidence-based practice guideline. Transfus Med Rev. 2010;24 Suppl 1:S28-50.

10. Lucas M, Lee M, Lortan J, Lopez-Granados E, Misbah S, Chapel $H$. Infection outcomes in patients with common variable immunodeficiency disorders: relationship to immunoglobulin therapy over 22 years. J Allergy Clin Immunol. 2010;125:1354-60.

11. Berger M. Incidence of infection is inversely related to steady-state (trough) serum IgG level in studies of subcutaneous IgG in PIDD. J Clin Immunol. 2011;31:924-6.

12. Orange JS, Grossman WJ, Navickis RJ, Wilkes MM. Impact of trough IgG on pneumonia incidence in primary immunodeficiency: a meta-analysis of clinical studies. Clin Immunol. 2010;137:21-30.

13. Bonagura VR, Marchlewski R, Cox A, Rosenthal DW. Biologic IgG level in primary immunodeficiency disease: the IgG level that protects against recurrent infection. J Allergy Clin Immunol. 2008; $122: 210-2$.

14. Jolles S, Bernatowska E, de Gracia J, Borte M, Cristea V, Peter $\mathrm{HH}$, et al. Efficacy and safety of Hizentra ${ }^{\circledR}$ in patients with primary immunodeficiency after a dose-equivalent switch from intravenous or subcutaneous replacement therapy. Clin Immunol. 2011;141:90-102.

15. Conley ME, Notarangelo LD, Etzioni A. Diagnostic criteria for primary immunodeficiencies. Representing PAGID (Pan-American Group for Immunodeficiency) and ESID (European Society for Immunodeficiencies). Clin Immunol. 1999;93:190-7.

16. Hagan JB, Fasano MB, Spector S, Wasserman RL, Melamed I, Rojavin MA, et al. Efficacy and safety of a new 20\% immunoglobulin preparation for subcutaneous administration, IgPro20, in patients with primary immunodeficiency. J Clin Immunol. 2010;30:734-45.

17. Borte M, Pac M, Serban M, Gonzalez-Quevedo T, Grimbacher B, Jolles S, et al. Efficacy and safety of Hizentra ${ }^{\circledR}$, a new $20 \%$ immunoglobulin preparation for subcutaneous administration, in pediatric patients with primary immunodeficiency. J Clin Immunol. 2011;31:752-61.

18. Eijkhout HW, van der Meer JW, Kallenberg CG, Weening RS, van Dissel JT, Sanders LA, et al. The effect of two different dosages of intravenous immunoglobulin on the incidence of recurrent infections in patients with primary hypogammaglobulinemia. A randomized, double-blind, multicenter crossover trial. Ann Intern Med. 2001;135:165-74. 
19. Quartier P, Debre M, De Blic J, de Sauverzac R, Sayegh N, Jabado $\mathrm{N}$, et al. Early and prolonged intravenous immunoglobulin replacement therapy in childhood agammaglobulinemia: a retrospective survey of 31 patients. J Pediatr. 1999;134:589-96.

20. Ochs HD, Fischer SH, Wedgwood RJ, Wara DW, Cowan MJ, Ammann AJ, et al. Comparison of high-dose and low-dose intravenous immunoglobulin therapy in patients with primary immunodeficiency diseases. Am J Med. 1984;76:78-82.

21. Roifman CM, Levison H, Gelfand EW. High-dose versus low-dose intravenous immunoglobulin in hypogammaglobulinaemia and chronic lung disease. Lancet. 1987;1:1075-7.

22. Liese JG, Wintergerst U, Tympner KD, Belohradsky BH. High- vs low-dose immunoglobulin therapy in the long-term treatment of X-linked agammaglobulinemia. Am J Dis Child. 1992;146:335-9.

23. Montanaro A, Pirofsky B. Prolonged interval high-dose intravenous immunoglobulin in patients with primary immunodeficiency states. Am J Med. 1984;76:67-72.

24. Bernatowska E, Madalinski K, Janowicz W, Weremowicz R, Gutkowski P, Wolf HM, et al. Results of a prospective controlled two-dose crossover study with intravenous immunoglobulin and comparison (retrospective) with plasma treatment. Clin Immunol Immunopathol. 1987;43:153-62.

25. Pruzanski W, Sussman G, Dorian W, Van T, Ibanez D, Redelmeier D. Relationship of the dose of intravenous gammaglobulin to the prevention of infections in adults with common variable immunodeficiency. Inflammation. 1996;20:353-9.

26. United States Department of Labor. Labor Force Statistics from the Current Population Survey. 46. Absences from work of employed full-time wage and salary workers by age, sex, race, and Hispanic or Latino ethnicity. 2011.

27. Wasserman RL, Melamed I, Nelson RP, Knutsen AP, Fasano MB, Stein MR, et al. Pharmacokinetics of subcutaneous IgPro20 in patients with primary immunodeficiency. Clin Pharmacokinet. 2011;50:405-14.

28. Favre O, Leimgruber A, Nicole A, Spertini F. Intravenous immunoglobulin replacement prevents severe and lower respiratory tract infections, but not upper respiratory tract and non-respiratory infections in common variable immune deficiency. Allergy. 2005;60:385-90. 